\title{
A Study on Steel Framed Residences in Terms of Energy Performance
}

\author{
Çelik Taşıyıcı Sistemli Konutların Enerji Korunumu Açısından \\ Değerlendirilmesine Yönelik Bir Çalışma
}

(D) Halet Almıla Arda BÜYÜKTAŞKIN, ${ }^{1}$ (1) Şule Filiz AKŞiT,' ${ }^{1}$ (1) Elif ÖZTÜRK²

The requirement for residential buildings has increased as a result of rapid population growth as well as emigrations caused by political and natural factors. Urbanization planners worldwide seek to find out new building construction technologies which are both environment friendly and capable of meeting the requirement of ever-increasing residence construction in a rapid and rational manner. In Turkey, most of the major towns are located in first and second degree earthquake zones. Following 1999 Kocaeli-Izmit Earthquake, structural steel has become the preferred structural material in the sector of residential building construction, and such use shall be further widespread in the coming years. In this study, the aim is to assess and evaluate such steel framed residences within 1st degree earthquake zones of Turkey in terms of energy conservation, upon ascribing emphasis on the variety of bearing systems as well. These steel framed residences examined in this study comply with "TS 825 Thermal Insulation Requirements for Buildings Standard" and "Regulation on the Energy Performance of Buildings".

Keywords: Energy conservation; energy efficiency; energy performance; steel framed residence; thermal insulation.

Hızlı nüfus artışı, siyasi ve doğal nedenlerle yaşanan göçler sonucu konut ihtiyacında sürekli bir artış görülmektedir. Dünya ülkeleri, artan konut ihtiyacının karşılanması için, sorunu hızlı ve rasyonel çözebilecek, dünya kaynaklarının ve enerjinin tasarruflu kullanımını sağlayacak, çevreyle uyumlu yeni yapı teknolojileri aramaktadır. Büyük şehirlerinin çoğu birinci ve ikinci derecede deprem bölgelerinde bulunan ülkemizde, 1999 Kocaeli-Izmit Depremi sonrasında, yapısal çelik malzemesinin, konut inşaatı sektöründe tercih edildiği ve bu kullanımın ileriki yıllarda daha da yaygınlaşacağı söylenebilir. Bu çalışmada, ülkemizdeki 1. derece deprem bölgesinde yer alan çelik taşıyıcı sistemli konut örneklerinin, taşıyıcı sistemleri de vurgulanarak enerji korunumu açısından değerlendirilmesi amaçlanmıştır. Ele alınan çelik taşıyıcı sistemli konutlar, 'TS 825 Binalarda Isı Yalıtım Kuralları' Standardı ve "Binalarda Enerji Performansı Yönetmeliği"ne uygunluğu ile sınanarak uygun bulunmuştur.

Anahtar sözcükler: enerji korunumu; enerji performansı; enerji etkinliği; çelik taşıyıcı sistemli konut; ısı yalıtımı. 


\section{Introduction}

In the contemporary world, the rapid emigration growth and population increase necessitate the construction of effective residence buildings. Therefore, urbanization planners worldwide seek to find out new building construction technologies which are both environment friendly and effective in the usage of global resources for dealing with the problem of residence shortage.

Throughout the course of their lifespans, buildings consume a considerable part of the natural resources and energy in the relevant phases of production, utilization and transformation, and as a result, more waste and pollution of environment are the inevitable outcomes. It is clearly obvious that these harmful side effects may increase with faster spread of residential constructions to accommodate growing population. To highlight the data obtained in Turkey on the sector of building construction:

- Investments in the building construction sector are currently made at most in the residential construction with the rate of $74.9 \%$.

- Since the emphasis on ecologic matters and on the sustainability of housing policies and programs has just emerged in Turkey's urban planning, the current available housing inventory turns out to be insufficient to serve the purpose.

- Due to the increase in fuel expenditures in the recent years, the insulation of housing residences with a share of $41 \%$ in the energy consumption of Turkey has become one of the major issues in the building construction.

- Failing to provide the climate comfort required to maintain a good interior air quality is largely jeopardizing habitants' health conditions.

- The use of structural steel in the building construction sector worldwide is as high as $60 \%$ among environmental friendly technologies used in the building construction. The constructional steel is currently being used only $5 \%$ of the constructions projects in Turkey. On the other hand, the steel industry in Turkey is equipped with a capacity of manufacturing a construction area of 7-10 million square meters. This rate is very low when compared to the other countries. The use of steel in the residence buildings in Turkey falls down to $0.5 \%$.

To be sure, since iron and steel are natural materials recyclable of high resistance and they provide high speed in construction, these materials will substitute traditional building construction technologies in the close future and they will expand their range of use from one day to the next as well.

In Turkey, most of the major towns are located in first and second degree earthquake zones. Following 1999 Ko-
caeli-Izmit Earthquake, steel has become the preferred structural material in the residential building construction sector, and and also enhancing energy efficiency shall be further widespread in the coming years.

Following the data mentioned above, it is clearly evident to define and determine technologies in building construction that are resistant to earthquakes, easy to manufacture, rapid to construct, possible to recycle and causing least possible damage on the environment.

Besides being dependent on the form, orientation, dimensions of the building and building's mode of utilization, the thermal transmission of exterior climatic conditions to the building's interior artificial ambient is highly correlated with the performance of the building envelope, the artificial environmental variable separating the internal ambience from the external.

\section{The Aim of the Study}

Energy consumption in residential buildings have been the subject of several researches. Mihalakakou et al. $(2002)^{1}$ trained a neural network models to investigate the hourly energy consumption values of a typical residential building located in Athens. Center for Sustainable Systems in Michigan University (2009)2 , has also carried out a research on residential buildings in the USA. According to this research:" Proven climate-specific, resource-efficient house design strategies exist, but due to lack of market incentives and political will, per capita materials and energy consumption continue to increase. Guertin $(2011)^{3}$ investigated a sustainable building in the field of materials and building construction via energy efficiency, construction practice and product selection.

Naji $(2012)^{4}$ studied three structural systems used in low-rise residential buildings, as wood light frame structure, light gauge steel frame structure, and 3D panels in terms of sustainability and energy efficiency.

The use of steel framed structures in residential buildings were also discussed in many studies. Taşkıran (2005) compared light weight steel, structural steel and reinforced concrete framed structures of three residential buildings in terms of cost analysis. Zaimoğlu (2006) ${ }^{6}$ examined examples of steel framed residential buildings with respect to preference reasons for slab, wall and roof structural elements and materials. Şahin $(2011)^{7}$ compared the steel system and reinforced concrete system in dwelling architecture with miscellaneous parameters such as construction costs, time, materials, labour, construction weights and recycling.

\footnotetext{
Mihalakakou et al., 2002.

2 Center for Sustainable Systems, 2009.

3 Guertin, 2011.

4 Naji, 2012.
}

\footnotetext{
5 Taşkıran, 2005.

6 Zaimoğlu, 2006.

7 Şahin, 2011.
} 


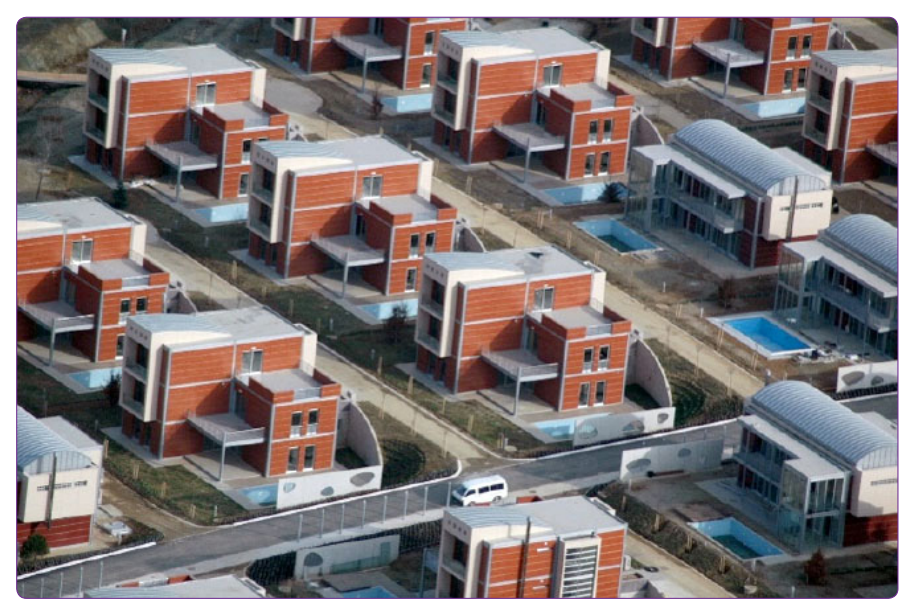

Figure 1. Millenium Park Residences.

From the previous researches, it can be observed that, the energy performance of residential buildings and the use of steel framed structures in residential buildings were examined oftenly as separate subjects. For this reason it is expected that, a research combining these two facts together would bring an original approach for academic and sectoral shareholders.

The main aim of this study is to evaluate the energy performance of steel framed residential buildings. To achieve this target, the article will examine several steel framed residential buildings in Turkey in terms of energy conservation. For this purpose, it is primarily set for the compliance of the building envelope with TS 825 Turkish Standard: Thermal Insulation Requirements for Building (2008). ${ }^{8}$ Thereafter, the results are evaluated by comparing building energy performances under Regulation on the Energy Performance of Buildings (2009). ${ }^{9}$

\section{Identification of Steel Framed Residences}

In order to meet the ever increasing need of residential accommodation, it is preferable to engage with building construction technologies which provide easy-manufacturing, rapid construction, recycling possibilities but cause least possible damage on the environment. The fact that steel is prefabricated in advance for construction substantially shortens the construction process. Furthermore, since steel construction is not dependent on weather conditions like concrete and operable at full load once it is assembled, steel is more advantageous for achieving fast construction rate if needed. Besides this, because it permits light-weighted structure to robust against earthquake load, the usage of steel bearing system becomes more convenient in building constructions at the earthquake zones.

Steel construction residences in Turkey are limited in number. In this study, steel construction residences, that we examine, are selected from amongst the major cities

\footnotetext{
8 TS 825, 2008. 9 Regulation on the Energy Performance of Buildings, 2009.
}

located in $1^{\text {st }}$ degree earthquake zones. These residential complexes are:

- Millenium Park Residences

- Tepe Ören Villas

- Kınalı Residences

- Anadolu Yakası Residences

- Kardelen Villas

\section{Millenium Park Residences}

Millenium Park Project, located at Istanbul, Kurtkoy, comprises of 3 different villa types, total 219 villas varying dimensions with an average area of 1287 square meters, constructed over a total area of 282.000 square meters. The project was constructed in the year of 2007 (Figure 1).

The residential complex is located within 1st degree earthquake zone. In this project, the bearing system is not concealed in the facade, but rather displayed. Bearing sys-

Table 1. Millenium Park Residences bearing system elements BEARING SYSTEM ELEMENT

\begin{tabular}{ll}
\hline Foundation & Reinforced Concrete Raft \\
& Foundation $(50 \mathrm{~cm})$ \\
Columns & 2xNPU 200 \\
Beams & NPI 200 \\
Secondary Beams & NPI 160 \\
Floor & Q188/188 Steel mesh \\
& reinforcement C30 concrete \\
& $(10 \mathrm{~cm})$ \\
Roof beams & NPI 200 \\
\hline
\end{tabular}

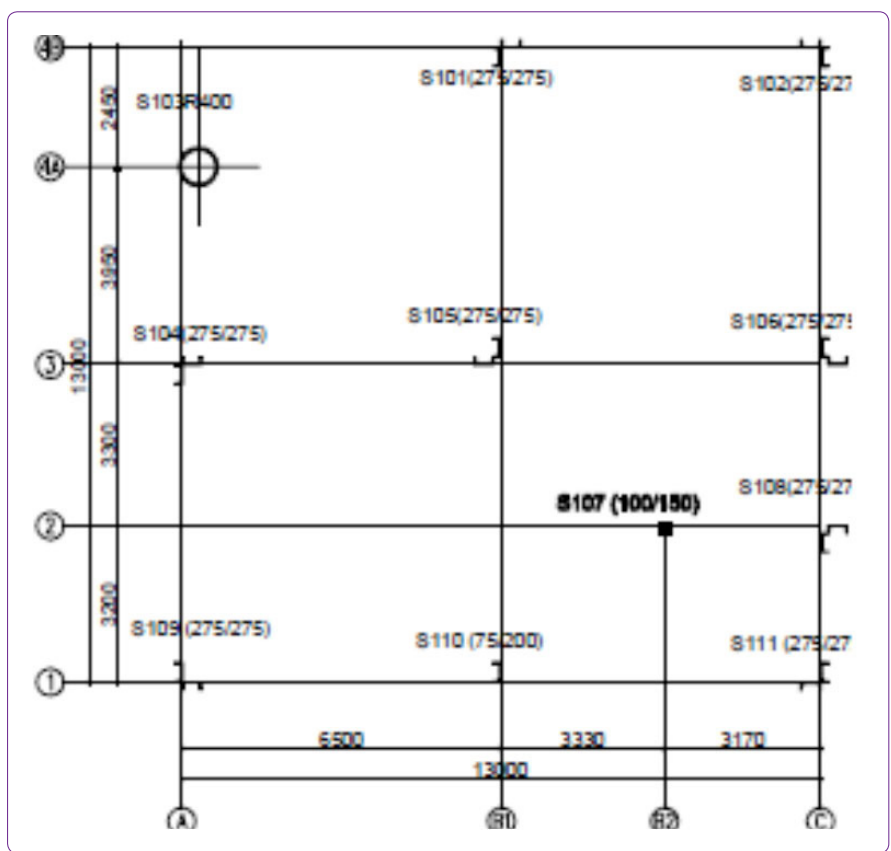

Figure 2. Millenium Park Residences Column Application Plan. 


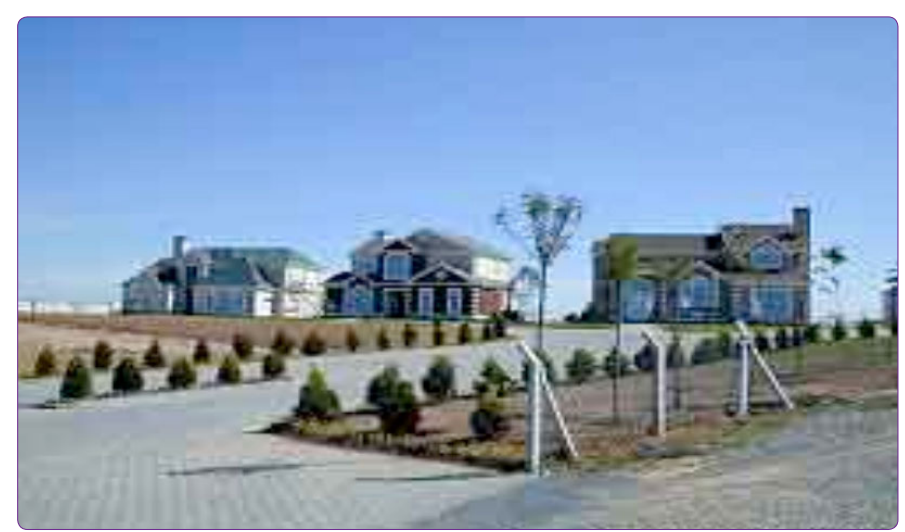

Figure 3. Tepe Ören Villas.

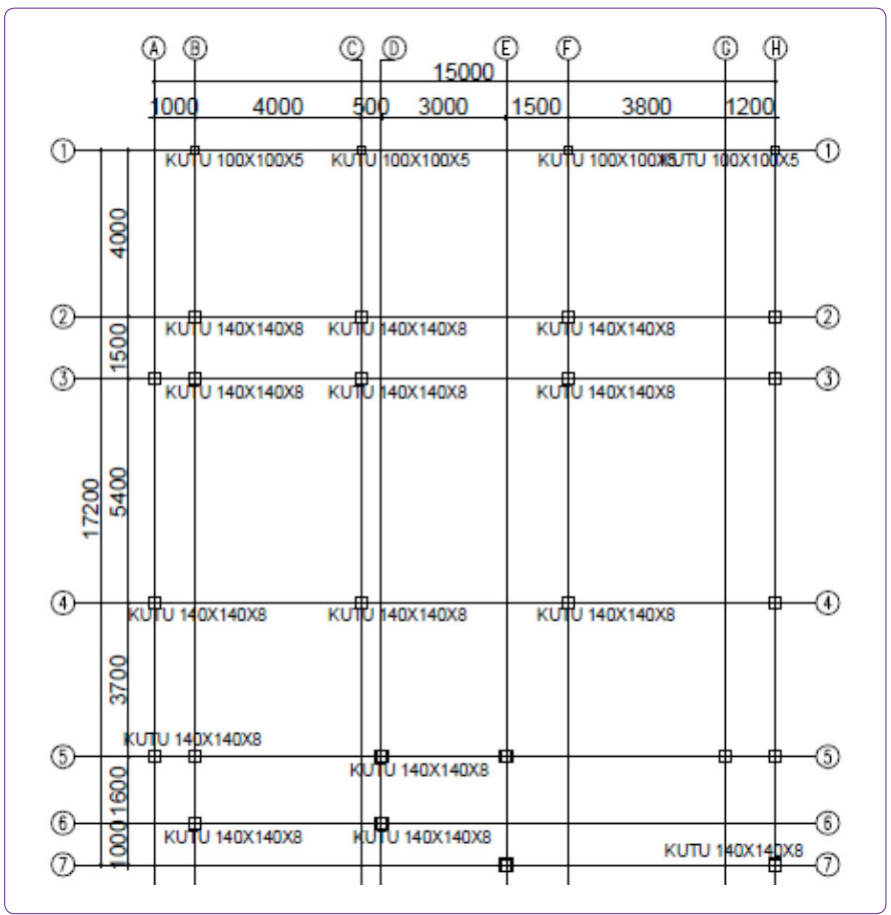

Figure 4. Tepe Ören Villas Column Application Plan.

Table 2. Tepe Ören Villas bearing system elements

\section{BEARING SYSTEM ELEMENT}

Foundation

Reinforced Concrete Raft Foundation $(35 \mathrm{~cm})$

Columns

Beams

Secondary Beams

Floor

tem elements are summarized on Table 1. Column application plan can be seen in Figure 2. $50 \times 70 \times 2$ box profile Q188/188 Steel mesh reinforcement $\mathrm{C} 30$ concrete $(8 \mathrm{~cm})$ $100 \times 60 \times 4$ box profile

\section{Tepe Ören Villas}

Tepe Ören Villas constructed in the year of 2009, situated at Istanbul, Tuzla, Tepe Ören location, comprise of 3 different villa types, total 101 villas varying sizes constructed over a land plot of 112 acres (Figure 3).

The residential complex is located within 1st degree earthquake zone. Bearing system elements are summarized on Table 2. Column application plan can be seen in Figure 4.

\section{Kınalı Residences}

The project of Kınalı Residences was started in the year of 2005 at Silivri, Istanbul. The project comprises of 300 villas over a total layout area of 55.000 square meters (Figure 5).

The residential complex is located within 1st degree earthquake zone. Bearing system elements are summarized on Table 3. Column application plan can be seen in Figure 6.

\section{Anadolu Yakası Residences}

Anadolu Yakası Residences is a project constructed in Aydin, Kuşadası in the year of 2006. Steel construction was the preferred choice in this project because of the fact that the location of Kuşadası is situated in the earthquake zone as well as the fact that the construction time for touristic areas is meant to be relatively short. 187 residences have been constructed within this project (Figure 7).

Residential complex is situated within $1^{\text {st }}$ degree earthquake zone. Bearing system elements are summarized on Table 4. Column application plan can be seen in Figure 8.

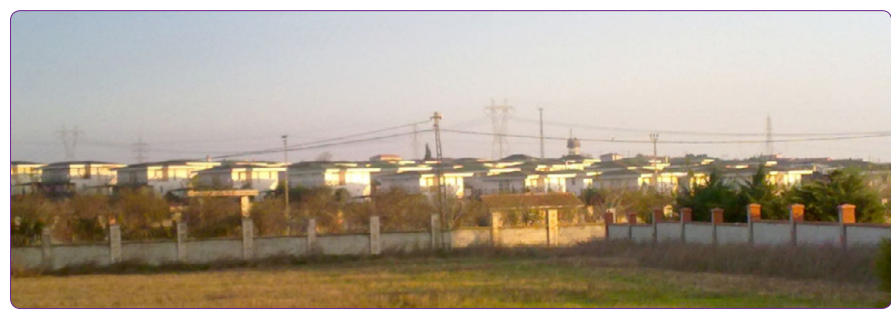

Figure 5. Kınalı Residences.

Table 3. Kınalı Residences bearing system elements

BEARING SYSTEM ELEMENT

Foundation

Reinforced Concrete Raft $250 \times 100 \times 6$ box profile

Columns

Beams

Secondary Beams

Floor Foundation $(50 \mathrm{~cm})$ NPU 300

castellated beam-360 NPI 160

Q188/188 Steel mesh reinforcement $\mathrm{C} 30$ concrete $(10 \mathrm{~cm})$

Roof beams castellated beam-200 


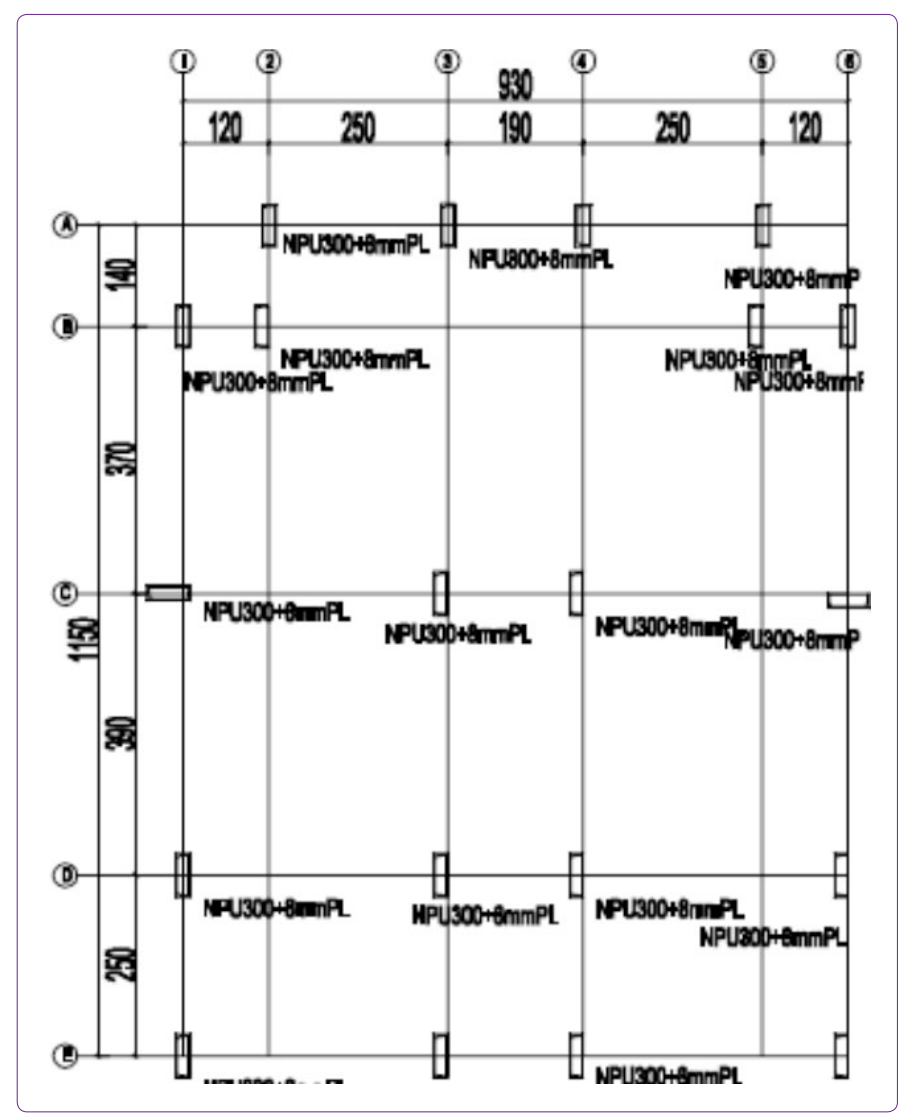

Figure 6. Kınalı Residences Column Application Plan.

\section{Kardelen Villas}

Kardelen Villas were constructed with steel bearing system over a land plot of 56 acres at Izmit, Kocaeli in the year of 2006, far from the noise and chaos of the city life, on a green area. The project comprises of 144 residences which are 160 square meters on the average (Figure 9).

Residential complex is located within $1^{\text {st }}$ degree earthquake zone. Bearing system elements are summarized on Table $5 .{ }^{10}$ Column application plan can be seen in Figure 10 .

\section{Assessment of Energy Performance of Steel Framed Residences}

In this inspection, it shall first of all be determined and specified the values regarding building envelope of those residences studied in respect to 'TS 825 Thermal Insulation Requirements for Buildings Standard (2008)', and thereafter the thermal performances of those residences shall be reviewed in accordance with 'Regulation on the Energy Performance of Buildings (2009)'.

Identification of the Heat Transfer Coefficient Values for the Building Envelope of Steel Framed Residences Studied

All of the building envelopes' details for each of the steel

\footnotetext{
10 Öztürk, 2012.
}

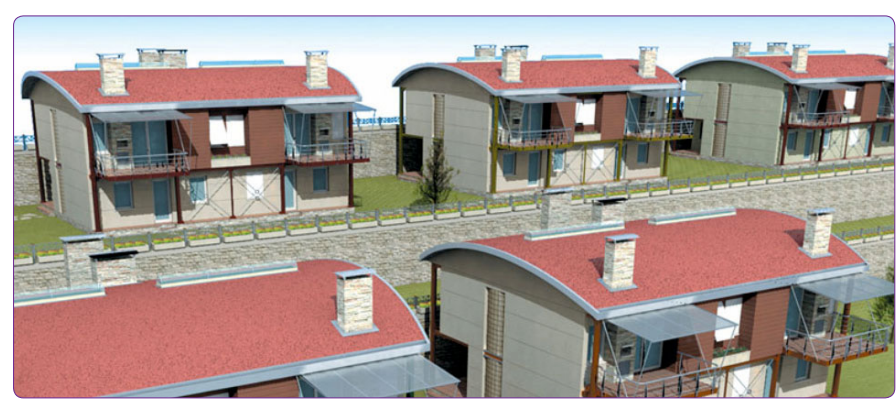

Figure 7. Anadolu Yakası Residences.

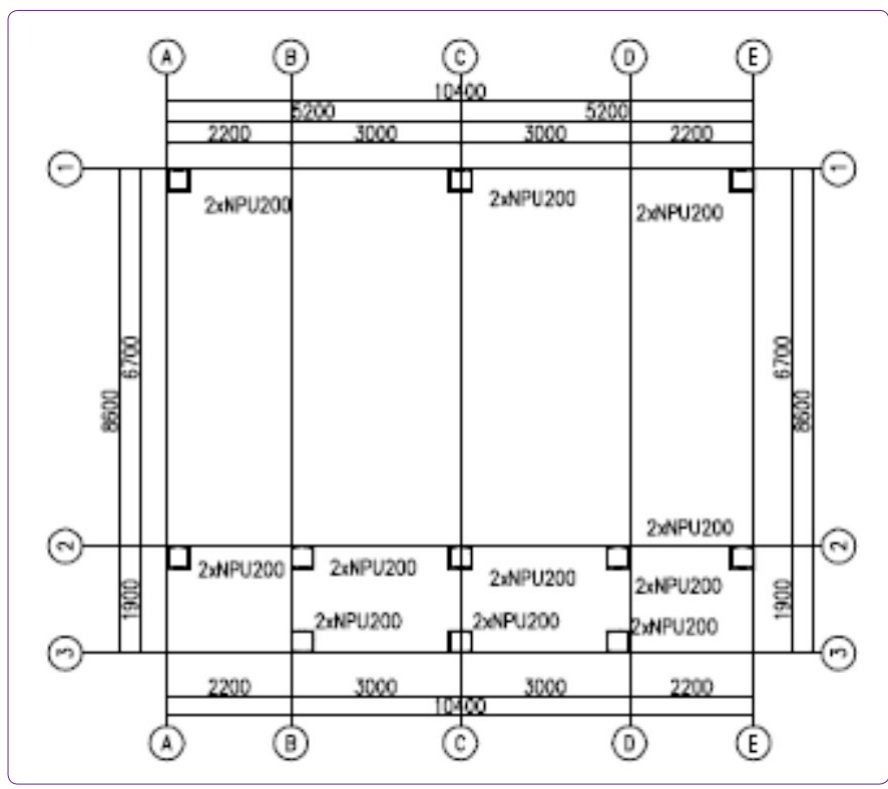

Figure 8. Anadolu Yakası Residences Column Application Plan.

Table 4. Anadolu Yakası Residences bearing system elements BEARING SYSTEM ELEMENT
Foundation

Columns

Beams

Secondary Beams

Floor

Roof beams
Reinforced Concrete Single Foundation 2xNPU 200 NPI 200 NPI 160 Q188/188 Steel mesh reinforcement $\mathrm{C} 30$ concrete $(10 \mathrm{~cm})$ NPI 200 framed residences are given in Figure 11 and Tables 6-10.

On Table 11, the values for overall heat transfer coefficient $(U)$ and the stratification details related to the building envelope (external wall, roof, and floor) wherefrom heat loss occurs in steel framed residences are listed. ${ }^{10}$ 


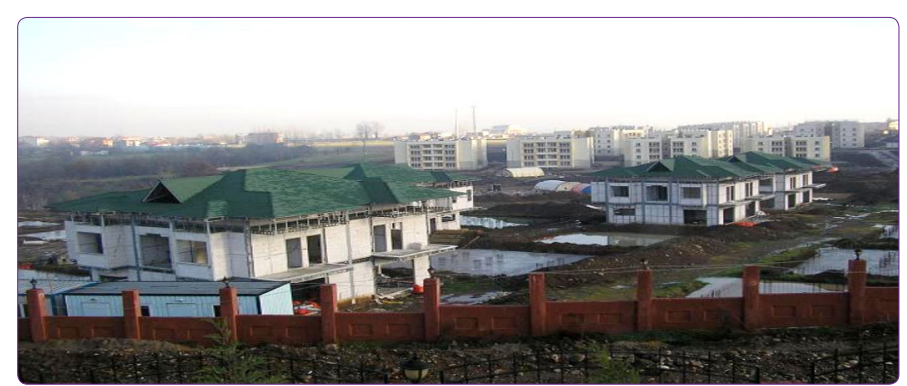

Figure 9. Kardelen Villas.

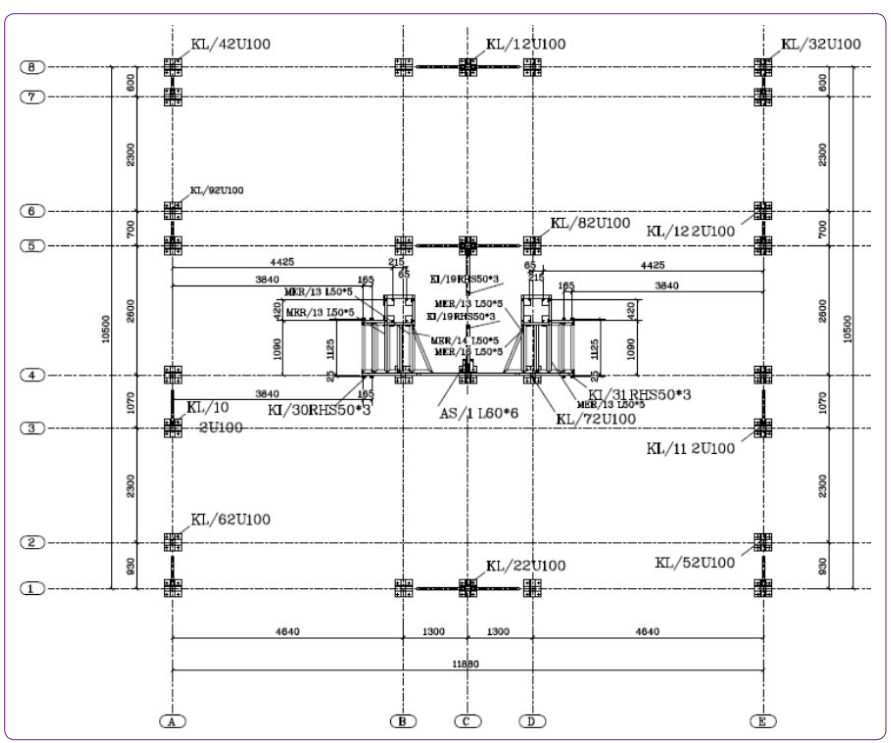

Figure 10. Kardelen Villas Column Application Plan.

Evaluation of the Thermal Performance of Steel Framed Residences Studied in accordance with 'TS 825 Thermal Insulation Requirements for Buildings Standard (2008)'

TS 825 Thermal Insulation Requirements for Buildings
Table 5. Kardelen Villas bearing system elements

\section{BEARING SYSTEM ELEMENT}

Foundation

Reinforced Concrete Raft Foundation $(50 \mathrm{~cm})$

Columns NPU 240

Beams

Secondary Beams

Floor

castellated beam-200

NPI 120

Q188/188 Steel mesh

reinforcement $\mathrm{C} 30$ concrete

$(10 \mathrm{~cm})$

Roof beams

Castellated main beam-140, NPU 100 secondary beam

Standard covers the rules of calculating the thermal energy requirement of buildings to be constructed as well as the regulations in case of modifications in the $15 \%$ and over of the accommodation space for the existing buildings. This standard determines the maximum allowed heat loss and the guideline for presenting thermal calculations. It introduces the limits on the amount of energy that could be lost in residences in Turkey and thereby enhances energy savings while it indicates the standard method and values for thermal calculation. The application of TS 825 calculation program permits to compare specific thermal loss in the buildings studied according to TS 825 Thermal Insulation Requirements for Buildings Standard and it serves to assess the compliance of the building designed in terms of energy efficiency and national legislations in practice.

In this section of the article, thermal performances of the steel framed residences mentioned are reviewed with the help of TS 825 program. The assessment criteria for

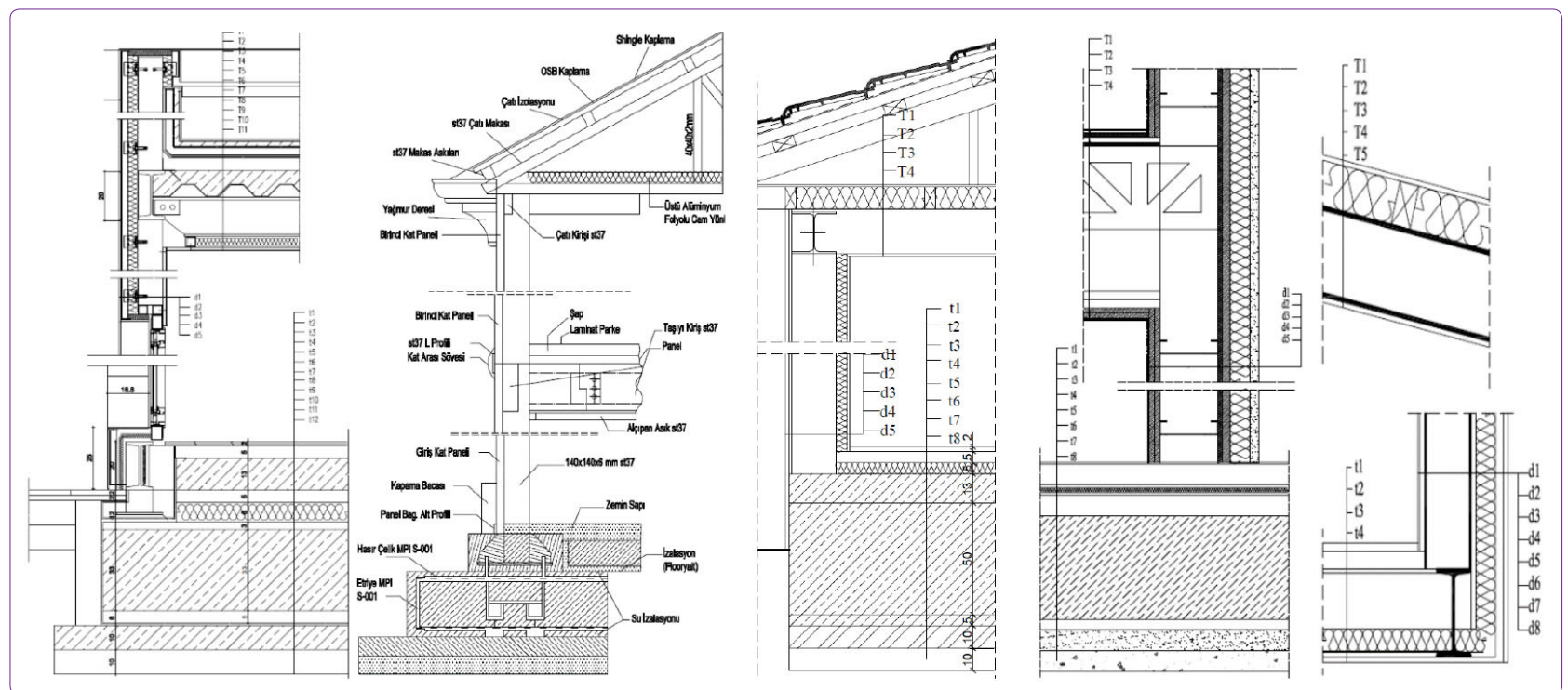

Figure 11. System Details respectively for Millenium Park, Tepe Ören, Kınalı, Anadolu Yakası and Kardelen Residences. 
Table 6. Building envelope details for Millenium Park Residences

\begin{tabular}{|c|c|c|c|c|c|}
\hline & $\begin{array}{l}\text { MILLENIUM PARK RESIDENCES } \\
\text { Materials }\end{array}$ & Code & $d(m)$ & $\lambda\left(\mathrm{W} / \mathrm{m}^{\circ} \mathrm{C}\right)$ & $\mathrm{U}\left(\mathrm{W} / \mathrm{m}^{2}{ }^{\circ} \mathrm{C}\right)$ \\
\hline \multirow[t]{4}{*}{ Exterior Wall } & Gypsum panel & $\mathrm{d} 2$ & 0.012 & 0.250 & 0.585 \\
\hline & Aerated concrete wall & d3 & 0.010 & 0.250 & \\
\hline & Extruded polystyrene foam & d4 & 0.050 & 0.035 & \\
\hline & Compact laminate panel & d5 & 0.006 & 0.260 & \\
\hline \multirow[t]{4}{*}{ Wall, adjacent to floor } & Gypsum panel & & 0.010 & 0.350 & 0.550 \\
\hline & Plain concrete & & 0.250 & 2.500 & \\
\hline & Extruded polystyrene foam & & 0.040 & 0.030 & \\
\hline & Brick wall & & 0.050 & 0.220 & \\
\hline \multirow[t]{3}{*}{ Wall, Column-Beam } & Gypsum panel & & 0.010 & 0.350 & 0.384 \\
\hline & Aerated concrete wall & & 0.150 & 0.140 & \\
\hline & Extruded polystyrene foam & & 0.040 & 0.030 & \\
\hline \multirow[t]{4}{*}{ Ceiling under an used attic } & Gypsum panel & & 0.010 & 0.350 & 0.588 \\
\hline & Air space & & 0.150 & & \\
\hline & Extruded polystyrene foam & & 0.050 & 0.040 & \\
\hline & Plywood bloackboard & & 0.012 & 0.130 & \\
\hline \multirow[t]{8}{*}{ Horizontal ceiling } & Gypsum panel & $\mathrm{T} 2$ & 0.010 & 0.350 & 0.302 \\
\hline & Extruded polystyrene foam & T3 & 0.050 & 0.035 & \\
\hline & NPI 160 & T4 & 0.160 & 0.100 & \\
\hline & Trapezoidal sheet & T5 & 0.001 & 0.000 & \\
\hline & Reinforced concrete & T6 & 0.100 & 2.500 & \\
\hline & Cement screed & $\mathrm{T} 7$ & 0.030 & 1.400 & \\
\hline & Cement screed & T10 & 0.020 & 1.400 & \\
\hline & Ceramic & T11 & 0.008 & 1.300 & \\
\hline \multirow[t]{12}{*}{ Floor on soil } & Cement screed & t2 & 0.050 & 1.400 & 0.303 \\
\hline & Plain concrete & t3 & 0.130 & 2.100 & \\
\hline & Cement screed & t4 & 0.050 & 1.400 & \\
\hline & Extruded polystyrene foam & t5 & 0.080 & 0.030 & \\
\hline & Cement screed & t6 & 0.030 & 1.400 & \\
\hline & Raft foundation & t7 & 0.330 & 2.100 & \\
\hline & Cement screed & t8 & 0.050 & 1.400 & \\
\hline & Geotextile $300 \mathrm{gr} / \mathrm{m}^{2}$ (polyethylene foil) & t9 & 0.003 & 0.190 & \\
\hline & Lean concrete & $\mathrm{t} 11$ & 0.100 & 2.100 & \\
\hline & Blokage & $\mathrm{t} 12$ & 0.100 & 2.100 & \\
\hline & Exterior window & & & & 2.7 \\
\hline & Exterior door & & & & 3.5 \\
\hline
\end{tabular}

these residences examined is that the annual heating energy requirement for these residences is to be lower than the maximum value specified in accordance with TS 825 Thermal Insulation Requirements for Buildings Standard.

For these steel framed residences studied, the calculations regarding the annual heating energy requirement obtained by TS 825 program are as given on Table 12 . As a result of the calculation, the maximum value required for heating requirements of the steel framed buildings studied is lower than the calculated annual heating energy requirement for buildings located in the $2^{\text {nd }}$ climatic zone. Consequently, all buildings tested turn out to be in com- pliance with TS 825 Thermal Insulation Requirements for Buildings Standard. ${ }^{11}$ As it can be observed from Table 12, calculated annual heating energy requirement for Kınalı Residences and Kardelen Villas is bigger than the other buildings. The main reason is that transparency ratios (window area/façade area) are higher.

Evaluation of the Thermal Performance of Steel Framed Residences Examined According to 'Regulation on the Energy Performance of Buildings'

The Regulation on the Energy Performance of Buildings

${ }^{11}$ Öztürk, 2012. 
Table 7. Building envelope details for Tepeören Villas

\begin{tabular}{|c|c|c|c|c|c|}
\hline & $\begin{array}{l}\text { TEPEÖREN VILLAS } \\
\text { Materials }\end{array}$ & Code & $d(m)$ & $\lambda\left(\mathrm{W} / \mathrm{m}^{\circ} \mathrm{C}\right)$ & $\mathrm{U}\left(\mathrm{W} / \mathrm{m}^{2}{ }^{\circ} \mathrm{C}\right)$ \\
\hline \multirow[t]{5}{*}{ Exterior Wall } & Gypsum panel & D1 & 0.012 & 0.25 & 0.265 \\
\hline & Air space & $\mathrm{D} 2$ & 0.140 & & \\
\hline & Glass foam & D3 & 0.035 & 0.045 & \\
\hline & Extruded polystyrene foam & D4 & 0.055 & 0.030 & \\
\hline & Glass foam & D5 & 0.035 & 0.045 & \\
\hline \multirow[t]{4}{*}{ Ceiling under an unused attic } & Plywood bloackboard & $\mathrm{T} 1$ & 0.012 & 0.130 & 0.653 \\
\hline & Roofmate & $\mathrm{T} 2$ & 0.020 & 0.290 & \\
\hline & Air space & T3 & 0.220 & & \\
\hline & Stone wool with aluminium foil & $\mathrm{T} 4$ & 0.040 & 0.040 & \\
\hline \multirow[t]{9}{*}{ Floor on soil } & Laminated parquetry & Do1 & 0.018 & 0.200 & 0.501 \\
\hline & Cement screed & Do2 & 0.080 & 1.400 & \\
\hline & Precast concrete panel & Do3 & 0.140 & 1.650 & \\
\hline & Floormate & Do4 & 0.030 & 0.024 & \\
\hline & Raft foundation & Do5 & 0.350 & 2.500 & \\
\hline & Lean concrete & Do6 & 0.100 & 1.650 & \\
\hline & Blokage & Do7 & 0.100 & 0.700 & \\
\hline & Exterior window & & & & 2.7 \\
\hline & Exterior door & & & & 4 \\
\hline
\end{tabular}

Table 8. Building envelope details for Kınalı Residences

\begin{tabular}{|c|c|c|c|c|c|}
\hline & $\begin{array}{l}\text { KINALI RESIDENCES } \\
\text { Materials }\end{array}$ & Code & $d(m)$ & $\lambda\left(W / m^{\circ} \mathbf{C}\right)$ & $\mathrm{U}\left(\mathrm{W} / \mathrm{m}^{2}{ }^{\circ} \mathrm{C}\right)$ \\
\hline \multirow[t]{5}{*}{ Exterior Wall } & Gypsum panel & d1 & 0.012 & 0.250 & 0.292 \\
\hline & Extruded polystyrene foam & $\mathrm{d} 2$ & 0.050 & 0.030 & \\
\hline & Aerated concrete wall & d3 & 0.200 & 0.140 & \\
\hline & Plywood bloackboard & $\mathrm{d} 4$ & 0.011 & 0.130 & \\
\hline & Gypsum mortar & d5 & 0.020 & 0.700 & \\
\hline \multirow[t]{6}{*}{ Wall, Column-Beam } & Gypsum panel & & 0.012 & 0.250 & 0.463 \\
\hline & NPU 300 & & 0.010 & 58.000 & \\
\hline & Air space & & 0.065 & & \\
\hline & Extruded polystyrene foam & & 0.050 & 0.030 & \\
\hline & Plywood bloackboard & & 0.010 & 0.130 & \\
\hline & Gypsum mortar & & 0.020 & 0.700 & \\
\hline \multirow[t]{4}{*}{ Ceiling under an used attic } & Gypsum panel & $\mathrm{T} 1$ & 0.018 & 0.250 & 0.295 \\
\hline & Air space & $\mathrm{T} 2$ & 0.200 & & \\
\hline & Stone wool & T3 & 0.100 & 0.035 & \\
\hline & Plywood bloackboard & $\mathrm{T} 4$ & 0.010 & 0.130 & \\
\hline \multirow[t]{7}{*}{ Horizontal ceiling } & Gypsum panel & & 0.012 & 0.250 & 0.496 \\
\hline & Cement screed & & 0.020 & 1.600 & \\
\hline & Reinforced concrete & & 0.100 & 2.500 & \\
\hline & Cement screed & & 0.050 & 1.400 & \\
\hline & Extruded polystyrene foam & & 0.050 & 0.030 & \\
\hline & Cement screed & & 0.050 & 1.400 & \\
\hline & Ceramic & & 0.008 & 1.300 & \\
\hline \multirow[t]{10}{*}{ Floor on soil } & Laminated parquetry & $\mathrm{t} 1$ & 0.018 & 0.200 & 0.404 \\
\hline & Cement screed & t2 & 0.050 & 1.400 & \\
\hline & Extruded polystyrene foam & $\mathrm{t} 3$ & 0.050 & 0.030 & \\
\hline & Precast concrete panel & $\mathrm{t} 4$ & 0.130 & 1.650 & \\
\hline & Raft foundation & t5 & 0.500 & 2.500 & \\
\hline & Plain concrete & t6 & 0.050 & 1.650 & \\
\hline & Precast concrete panel & t7 & 0.100 & 1.650 & \\
\hline & Blokage & t8 & 0.100 & 0.700 & \\
\hline & Exterior window & & & & 2.7 \\
\hline & Exterior door & & & & 3.5 \\
\hline
\end{tabular}


Table 9. Building envelope details for Anadolu Yakası Residences

\begin{tabular}{|c|c|c|c|c|c|}
\hline & $\begin{array}{l}\text { ANADOLU YAKASI RESIDENCES } \\
\text { Materials }\end{array}$ & Code & $d(m)$ & $\lambda\left(W / m^{\circ} \mathrm{C}\right)$ & $\mathrm{U}\left(\mathrm{W} / \mathrm{m}^{2}{ }^{\circ} \mathrm{C}\right)$ \\
\hline \multirow[t]{6}{*}{ Exterior wall } & Gypsum panel & d1 & 0.012 & 0.250 & 0.462 \\
\hline & Air space & d3 & 0.120 & 0.750 & \\
\hline & Plywood bloackboard & d5 & 0.012 & 0.130 & \\
\hline & Extruded polystyrene foam & d6 & 0.050 & 0.030 & \\
\hline & Ceramic binder & $d 7$ & 0.020 & 0.700 & \\
\hline & Gypsum panel & $\mathrm{d} 8$ & 0.012 & 0.250 & \\
\hline \multirow[t]{4}{*}{ Wall, Column } & Air space & & 0.150 & 0.938 & 0.932 \\
\hline & Extruded polystyrene foam & & 0.020 & 0.030 & \\
\hline & Ceramic binder & & 0.020 & 0.700 & \\
\hline & Gypsum panel & & 0.012 & 0.250 & \\
\hline \multirow[t]{3}{*}{ Wall, Beam } & Air space & & 0.130 & 0.813 & 0.482 \\
\hline & Extruded polystyrene foam & & 0.050 & 0.030 & \\
\hline & Ceramic binder & & 0.020 & 0.700 & \\
\hline \multirow[t]{4}{*}{ Ceiling under an used attic } & Gypsum panel & $\mathrm{T} 1$ & 0.012 & 0.250 & 0.297 \\
\hline & Air space & $\mathrm{T} 2$ & 0.200 & 1.250 & \\
\hline & Stone wool & T3 & 0.100 & 0.035 & \\
\hline & Plywood bloackboard & T4 & 0.012 & 0.130 & \\
\hline \multirow{6}{*}{$\begin{array}{l}\text { Floor that separate exterior } \\
\text { conditions }\end{array}$} & Cement screed & $\mathrm{t} 1$ & 0.040 & 1.400 & 0.680 \\
\hline & NPU 200 & $\mathrm{t} 2$ & 0.150 & 0.714 & \\
\hline & Extruded polystyrene foam & t3 & 0.050 & 0.035 & \\
\hline & Plywood bloackboard & $\mathrm{t} 4$ & 0.012 & 0.130 & \\
\hline & Exterior window & & & & 2.7 \\
\hline & Exterior door & & & & 3.5 \\
\hline
\end{tabular}

shows the standard setting methods and principles with respect to effective and efficient use of energy and energy sources in buildings. This regulation drew up a guideline for avoiding energy waste and securing environment. It covers the following standing rules concerning existing buildings as well as buildings to be constructed:

- Calculation methods, standards, practices and minimum performance criteria regarding the preparation and implementation of building projects and energy identity certificate for matters related to energy utilization of the building such as architectural design, mechanical installation, lighting, electrical installation,

- Authorizations with respect to issuance of energy identity certificate, building controls as well as audit operations,

- Meeting the energy requirement with the cogeneration system and renewable energy sources,

- Awareness raising activities and training for the improvement of the energy culture and efficiency consciousness in the community for building inventory throughout the country in general and applying the necessary updates for these operations.

In order to realize the objectives of the energy performance regulation, legislation aims that all buildings in
Turkey possess an energy identity certificate. Such energy identity certificate is given along with Bep-TR software program (Energy Performance of Buildings) by authorized institutions.

In this section of the article, the energy categories of steel framed residences in examination are identified in accordance with "Regulation on the Energy Performance of Buildings" by using Bep-TR software program. According to the evaluation criteria for the regulation of the energy performance for the residential buildings, the overall energy class of the steel framed residences in examination must be minimum 'Class C'.

At the end of identification of the overall energy class for the steel framed residences through Bep-TR software program, Millenium Park Residences, Tepeören Villas, Anadolu Yakası Residences, Kardelen Villas are defined as 'Class C' and the overall energy class of Kınalı Residences qualified as 'Class B' (Table 13). These findings are confined within prescribed limits for residential buildings.

\section{Conclusion and Recommendations}

In today's world, natural energy resources are rapidly running out. The use of natural resources in a conscious manner while creating a sustainable artificial environment in terms of energy conservation became the priority issue. To serve this objective, designing energy-efficient build- 
Table 10. Building envelope details for Kardelen Villas

\begin{tabular}{|c|c|c|c|c|c|}
\hline & $\begin{array}{l}\text { KARDELEN RESIDENCES } \\
\text { Materials }\end{array}$ & Code & $d(m)$ & $\lambda\left(W / m^{\circ} \mathrm{C}\right)$ & $\mathrm{U}\left(\mathrm{W} / \mathrm{m}^{2}{ }^{\circ} \mathrm{C}\right)$ \\
\hline \multirow[t]{5}{*}{ Exterior wall } & Gypsum mortar & d1 & 0.020 & 0.510 & 0.298 \\
\hline & Gypsum panel & $\mathrm{d} 2$ & 0.012 & 0.250 & \\
\hline & Air space & d3 & 0.200 & 1.250 & \\
\hline & Precast concrete panel & $\mathrm{d} 4$ & 0.020 & 0.250 & \\
\hline & Extruded polystyrene foam & d5 & 0.100 & 0.035 & \\
\hline \multirow[t]{4}{*}{ Wall, Column-Beam } & Gypsum mortar & & 0.020 & 0.510 & 0.730 \\
\hline & Air space & & 0.075 & 0.441 & \\
\hline & Precast concrete panel & & 0.020 & 0.150 & \\
\hline & Extruded polystyrene foam & & 0.030 & 0.035 & \\
\hline \multirow[t]{4}{*}{ Ceiling under an used attic } & Gypsum panel & $\mathrm{T} 1$ & 0.010 & 0.250 & 0.193 \\
\hline & Air space & $\mathrm{T} 2$ & 0.120 & 0.080 & \\
\hline & Extruded polystyrene foam & T3 & 0.100 & 0.030 & \\
\hline & Precast concrete panel & $\mathrm{T} 4$ & 0.020 & 0.150 & \\
\hline \multirow{5}{*}{$\begin{array}{l}\text { Floor that separate exterior } \\
\text { conditions }\end{array}$} & Laminated parquetry & & 0.018 & 0.000 & 0.362 \\
\hline & Reinforced concrete & & 0.100 & 2.500 & \\
\hline & Extruded polystyrene foam & & 0.050 & 0.035 & \\
\hline & Air space & & 0.070 & 0.067 & \\
\hline & Gypsum panel & & 0.010 & 0.250 & \\
\hline \multirow[t]{10}{*}{ Floor on soil } & Ceramic & $\mathrm{t} 1$ & 0.010 & 1.300 & 0.420 \\
\hline & Cement screed & t2 & 0.050 & 1.400 & \\
\hline & Extruded polystyrene foam & t3 & 0.050 & 0.030 & \\
\hline & Plain concrete & t4 & 0.100 & 1.650 & \\
\hline & Raft foundation & t5 & 0.500 & 2.500 & \\
\hline & Cement screed & t6 & 0.050 & 1.400 & \\
\hline & Lean concrete & t7 & 0.100 & 1.650 & \\
\hline & Blokage & t8 & 0.100 & 0.700 & \\
\hline & Exterior window & & & & 2.2 \\
\hline & Exterior door & & & & 3.5 \\
\hline
\end{tabular}

Table 11. Overall Heat Transfer Coefficient $\left(U, W / \mathrm{m}^{2}{ }^{\circ} \mathrm{C}\right)$ Values of the Building Envelope

\begin{tabular}{|c|c|c|c|c|c|c|c|}
\hline & $\begin{array}{c}\text { WALL } \\
\text { Open To } \\
\text { Atmosphoric Effects }\end{array}$ & $\begin{array}{l}\text { WALL } \\
\text { Column } \\
\text { Beam }\end{array}$ & $\begin{array}{l}\text { CEILING } \\
\text { Attic In } \\
\text { Use }\end{array}$ & $\begin{array}{l}\text { CEILING } \\
\text { Terrace } \\
\text { Roof }\end{array}$ & $\begin{array}{c}\text { FLOOR } \\
\text { In Contract } \\
\text { With Ground }\end{array}$ & $\begin{array}{c}\text { Outer } \\
\text { window }\end{array}$ & $\begin{array}{l}\text { Outer } \\
\text { door }\end{array}$ \\
\hline Millenium Park Residences & 0.586 & 0.384 & 0.588 & 0.302 & 0.303 & 2.7 & 3.5 \\
\hline Tepe Ören Villas & 0.265 & 0.265 & 0.653 & - & 0.501 & 2.7 & 4 \\
\hline Kınalı Residences & 0.292 & 0.463 & 0.295 & 0.496 & 0.404 & 2.7 & 3.5 \\
\hline Anadolu Yakası Residences & 0.462 & $\begin{array}{l}0.932 \\
0.482\end{array}$ & 0.297 & - & - & 2.7 & 3.5 \\
\hline Kardelen Villas & 0.298 & 0.730 & 0.193 & - & 0.420 & 2.2 & 3.5 \\
\hline
\end{tabular}

ings should constitute one of our most essential tasks as architects and engineers.

In this article, steel framed residences which have expanded its application field particularly after 1999 IzmitKocaeli earthquake in Turkey are studied. This study is primarily conducted to examine the bearing systems of the residential complexes and thereafter to assess their thermal performances according to TS 825 Thermal Insulation Requirements for Buildings Standard and Regulation on the Energy Performance of Buildings. As a result of the assessment, those buildings determined to have been constructed in compliance with TS 825 Thermal Insulation Requirements for Buildings Standard, are then inspected and evaluated according to Regulation on the Energy Performance of Buildings. At the end of the inspection, it is detected that residences studied display the overall energy class of 'Class C'.

The suggestions developed as the result of the study are listed here below;

- Since it is expected to be mandatory for all buildings 
Table 12. Annual heating energy requirements calculated through TS 825 program

\begin{tabular}{lcr} 
Steel Framed Residences & \multicolumn{1}{c}{ Annual heating energy requirement $\left(\mathbf{k W h} / \mathbf{m}^{\mathbf{3}}\right)$} \\
\cline { 2 - 3 } & \multicolumn{1}{c}{ Calculated value } & Maximum value \\
\hline Millenium Park Residences & $22.49 \mathrm{kWh} / \mathrm{m}^{3}$ & $22.56 \mathrm{kWh} / \mathrm{m}^{3}$ \\
Tepe Ören Villas & $22.11 \mathrm{kWh} / \mathrm{m}^{3}$ & $24.94 \mathrm{kWh} / \mathrm{m}^{3}$ \\
Kınalı Residences & $70.69 \mathrm{kWh} / \mathrm{m}^{3}$ & $71.53 \mathrm{kWh} / \mathrm{m}^{3}$ \\
Anadolu Yakası Residences & $13.30 \mathrm{kWh} / \mathrm{m}^{3}$ & $15.20 \mathrm{kWh} / \mathrm{m}^{3}$ \\
Kardelen Villas & $76.19 \mathrm{kWh} / \mathrm{m}^{3}$ & $77.84 \mathrm{kWh} / \mathrm{m}^{3}$
\end{tabular}

Table 13. Identifications of overall energy class through Bep-TR software program

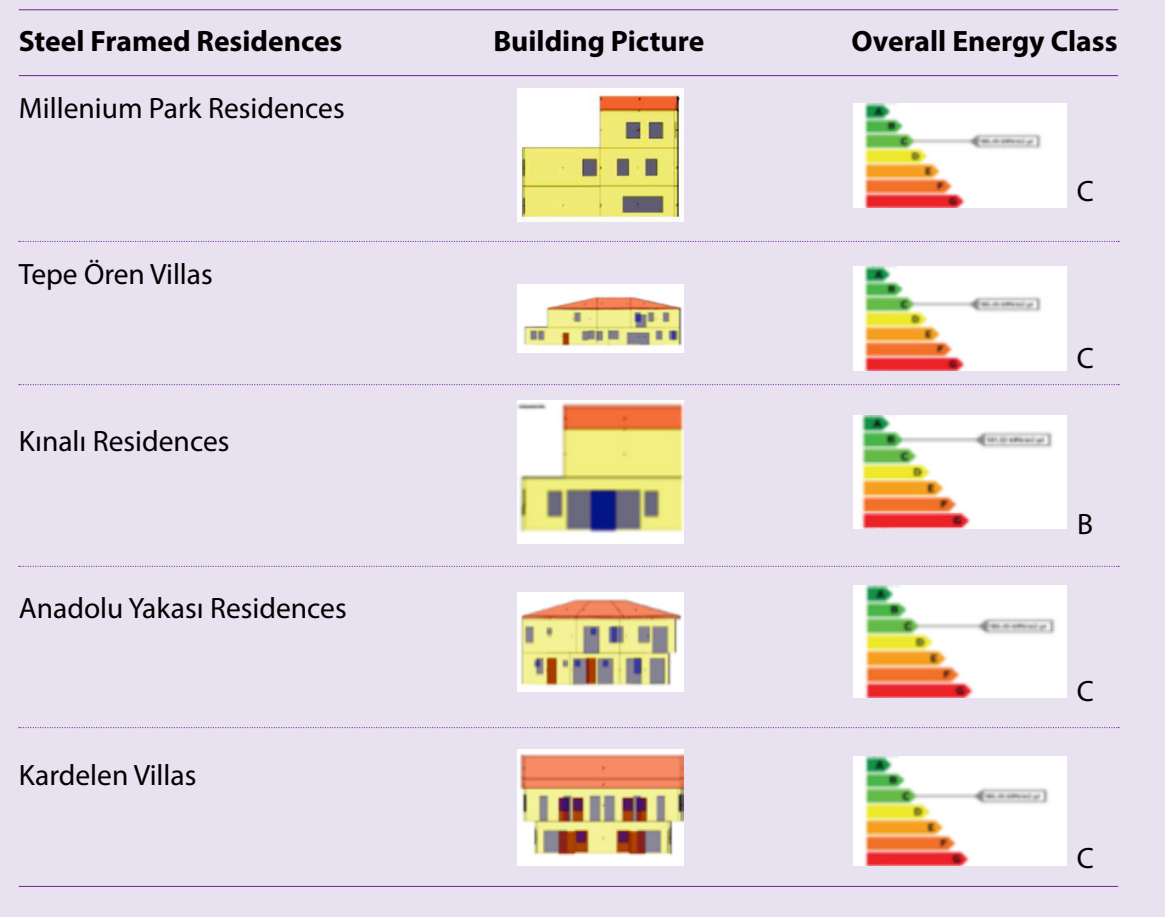

to receive "Energy Identity Certificate" in the next years, in Turkey and it would be costly to make any later interventions in the existing building structure for enhancing energy-efficiency, the buildings should be designed to be energy-efficient at the early stage of the project.

- In the entire world, there are lots of studies on energy-efficiency of buildings and both voluntary and mandatory applications of these studies. However, in countries like Turkey where the subject matter is getting recently well-known, it is required to keep the community informed and provide incentives related to energy-efficiency of buildings. Designers, constructors as well as users should be encouraged for energy-efficient designs through training, promotion, tax deduction and such similar ways.
- Steel construction is an extremely fast mode of construction system. The main bearing system is erected within short notice regardless of weather conditions and the manufacture can be completed on a turnkey basis in residential type buildings. There is no specific "construction season". Since steel is prefabricated in the manufacturer facility therefore it eliminates timeconsuming activities in the building construction. Through easy and rapid transport, fast and practical assembly means, steel construction allows to spend minimum time and labor power hereby it offers maximum construction convenience at the construction site thanks to its quick assembly erection. In addition to this, the early completion of the building provides advantages in terms of sales and rental revenues as well. The lifespan of steel structured is relatively long. Consequently, steel structure can promise a secure 
and reliable accommodation for several next generations for habitants. Besides this, it is possible to recycle and reuse the steel bearing system. Moreover, its maintenance requirements are easy to handle, almost negligible; it offers unlimited solutions to meet with the requirements of renewal and replacement. Therefore, any modifications and refurbishments for the building become mostly easy and affordable. This keeps the market value of the building high throughout its entire lifespan. Therefore, steel construction offers perfectly a reasonable choice of investment. ${ }^{12}$

In Turkey as an earthquake prone country, it is beyond a doubt that the usage of steel in the residential building construction sector would be ultimately the best choice. Steel structures are best at resisting earthquakes because of the fact that steel possesses a homogeneous and isotropic character and both tensile and compression strength of steel are very high..$^{13}$ Besides this, steel as a ductile material with high-load capacity in comparison to its low density and this qualification of steel permits its application for weak ground conditions. Consequently, the reasons and advantages for the steel construction must not be ignored in the residential construction sector.

\section{References}

Arda Büyüktaşkın, H.A., Arda, T.S. (2000) "17th of August 1999-Izmit (Kocaeli) Earthquake and its Effects on Different Constructions", International Conference of Steel Structures of the 2000's, Istanbul Technical University and Turkish Constructional Steelwork Association and ECCS European Con- vention for Constructional Steelwork, Proceedings, 2000, Istanbul, p. 1-6.

Center for Sustainable Systems (2009) "Residential Buildings Factsheet", University of Michigan, Pub. No. CSS01-08.

Guertin M. (2011) “Green Applications for Residential Construction", Residential Construction Academy, Delmar, Cengage Learning, USA.

Mihalakakou G. et al. (2002) "On the Energy Consumption in Residential Buildings", Journal of Energy and Buildings 34(7), p. 727-736.

Naji S. (2012) "Comparative Evaluation Among Three Structural Systems for Low-Rise Energy Efficient Residential Buildings", Master's Thesis, Graduate School of Science Engineering and Technology, Istanbul Technical University, Istanbul, Turkey.

Şahin Y.E. (2011) "Comparing the Steel System and Reinforced Concrete System in Dwelling Architecture with Miscellaneous Parameters", Master's Thesis, Institute of Natural and Applied Sciences, Çukurova University, Adana, Turkey.

Taşkıran E. (2005) "Design of Residential Houses Using Steel Framing Systems", Master's Thesis, Graduate School of Natural and Applied Sciences, 9 Eylül University, Izmir, Turkey.

Öztürk, E. (2012) "A Study about the Evaluation of Steel Structure Houses in terms of Their Energy Savings", Master's Thesis, Graduate School of Science Engineering and Technology, Istanbul Technical University, Istanbul, Turkey.

Zaimoğlu M. (2009) "Study of Structural Element Choices in Steel Framed Houses on Examples", Master's Thesis, Graduate School of Science Engineering and Technology, Istanbul Technical University, Istanbul, Turkey.

Enerji Performansı Yönetmeliği (2009) "Regulation on Energy Performance", Turkish Standard Institute.

TS 825 (2008) "Binalarda Isı Yalıtım Yönetmeliği", Regulation on Thermal Insulation in Buildings, Turkish Standard Institute. 